\title{
REMITTANCES OVER THE BUSINESS CYCLE: THEORY AND EVIDENCE
}

\author{
Supriyo De \\ Ergys Islamaj \\ M. Ayhan Kose \\ S. Reza Yousefi
}

Working Paper 1601

March 2016

This Working Paper is issued under the supervision of the ERF Directorate. Any opinions expressed here are those of the author(s) and not those of the Koç University-TÜSİAD Economic Research Forum. It is circulated for discussion and comment purposes and has not been subject to review by referees.

KOÇ UNIVERSITY-TÜSİAD ECONOMIC RESEARCH FORUM

Rumelifeneri Yolu 34450 Sariyer/Istanbul 


\title{
Remittances over the Business Cycle: Theory and Evidence
}

\author{
Supriyo De, Ergys Islamaj, M. Ayhan Kose, and S. Reza Yousefi ${ }^{1}$
}

March 2016

\begin{abstract}
This paper examines the behavior of remittances over the business cycle and their potential to act as a stabilizer during periods of high business cycle volatility. Four main findings are reported. First, in theory, the cyclical behavior of remittances depends on the motives to remit. Second, remittances are less volatile than other foreign currency flows but do not appear to systemically co-move with business cycle fluctuations. Third, remittances are relatively stable even during episodes of sharp business cycle volatility, such as those associated with sudden stops and financial crises. Finally, remittances can help support consumption stability over the business cycle.
\end{abstract}

Keywords: remittances, business cycles, acyclical, sudden stops, risk sharing. JEL Classification Numbers: F24, F36, F41, F44

\footnotetext{
${ }^{1}$ Supriyo De is Consultant at the World Bank (sde@worldbank.org); Ergys Islamaj is Economist at the World Bank (Corresponding author, eislamaj@worldbank.org); Ayhan Kose is Director at the World Bank, Nonresident Senior Fellow at the Brookings Institution, Research Fellow at the Center for Economic Policy Research (CEPR), and Research Associate at the Center for Applied Macroeconomic Analysis (CAMA) (akose@worldbank.org); and Seyed Reza Yousefi is Economist at the IMF (s.reza.y@gmail.com). The authors appreciate Sanket Mohapatra for his background input and extensive comments. We thank Pablo Acosta, Poonam Gupta, Andrea Presbitero, Dilip Ratha, Sergio Schmukler, Nikola Spatafora, Dana Vorisek and participants at the GCER May 2015 Conference, the 8th International Conference on Migration and Development, and a KNOMAD Brown Bag Seminar for their useful suggestions, and Sherrie Brown for editorial help.
} 


\section{Introduction}

Remittances to developing countries since 2000 have been significant both as a share of GDP and compared with foreign direct investment (FDI) and official development assistance (ODA) (Figures 1 and 2). Given their size and the fact that they are used to fund consumption needs of the recipients, remittances have the potential to counterbalance adverse output effects during economic downturns and sudden stops in capital flows. However, the potential of remittances to act as a counterbalance depends on how remittances behave during business cycle fluctuations. If remittances are countercyclical, then they could help smooth macroeconomic fluctuations. However, if they are procyclical, they could amplify business cycle fluctuations.

In theory, the behavior of remittances over the cycle is related to the motives to remit. In the broadest categorization, remittances can be driven by either altruism or self-interest (Lucas and Stark 1985; Amuedo-Dorantes and Pozo 2006). In the former case, remittances are believed to be unrequited transfers without expectations of personal gain sent to relatives during large shocks and tend to be countercyclical. In the latter case, remittances are usually used for investment in the home country and are likely to be procyclical with respect to the business cycle of the recipient economy.

The empirical literature on the cyclical behavior of remittances has been inconclusive. Some studies find that remittances are largely altruistic and countercyclical with respect to the recipient economy (Frankel 2011; Bettin, Presbitero, and Spatafora 2015). Other studies challenge these results and report that the investment-driven, procyclical tendency may be more prevalent (Lueth and Ruiz-Arranz 2008; Guiliano and Ruiz-Arranz 2009). Durdu and Sayan (2010) document that whereas countercyclical remittances flows can mitigate macroeconomic volatility, procyclical flows have the potential to deepen it. ${ }^{2}$ The behavior of remittances during episodes of high macroeconomic volatility during current account reversals and financial crises, and their potential to stabilize consumption in response to income shocks, remain understudied in the literature.

Because of the limited research on the dynamic patterns of remittances, many important questions remain unanswered. This paper addresses three main questions: First, what is the behavior of remittances over the business cycle and how does that compare with the behavior of other inflows, such as FDI, portfolio equity, and ODA? Second, how do remittances change during sudden stops and financial crises? Third, can remittances help stabilize consumption?

This analysis adds to the literature in several ways: First, it provides a broad overview of the theoretical literature on the motives to remit and the implications that these motives have for the

2. A few studies have investigated the ability of remittances to help reduce macroeconomic volatility. These studies vary in country coverage and methodology. Amuedo-Dorantes and Pozo (2011); Craigwell, Jackman, and Moore (2010); Bugamelli and Paterno (2011); and Chami, Hakura, and Montiel (2012) find that remittances are negatively correlated with output growth volatility. Balli and Ozer-Balli (2011) study the extent to which remittances contribute to better income risk sharing for the Pacific Island countries and find substantial effects. 
behavior of remittances flows over the business cycle. Second, it documents a number of stylized facts about the cyclical dynamics of remittances. More specifically, it revisits the cyclical features of remittances for a widely inclusive set of 109 countries for the period 1980-2012. It also provides a comparison of different methodologies used in the literature to analyze the cyclical features of remittances. Third, it investigates the behavior of remittances during episodes of sudden stops and during financial crises. Finally, it empirically tests whether remittances inflows are correlated with better consumption stability.

The main empirical findings are the following: First, remittances are largely acyclical with respect to the recipient country. In addition, remittances are less volatile than other types of inflows, including FDI and ODA. At the same time, remittances are less procyclical than financial flows, but more procyclical than ODA. Second, remittances display resilience during sudden stops and financial crises. Whereas total inflows decline sharply during these episodes, remittances stay stable. Third, empirical analysis does indeed show that remittances have helped counterbalance the effects of volatile financial flows.

The rest of the paper is organized as follows. Section 2 provides a broad overview of the theoretical underpinnings of the motives to remit. Section 3 describes the data. Section 4 documents the cyclicality and volatility of remittances and analyzes the behavior of remittances during sudden stops and financial crises. Section 5 shows the effects of remittances on consumption smoothing. Section 6 offers some concluding remarks and suggestions for future work.

\section{Cyclical Behavior of Remittances in Theory}

In theory, the cyclical properties of remittances are closely related to the motives that drive remittances. At the individual level, these motives have direct implications for the amount, timing, and frequency of remittances. At the aggregate level, they may affect the volume of flows and their variability across economic ups and downs, in both the remittances origin and recipient countries. This section discusses the drivers of remittances and their implications for the business cycle features of remittances with respect to the origin and recipient economies. Remittances are driven by either altruistic motives or self-interest. In the former case they usually tend to be countercyclical. In the latter case, they are largely procyclical.

\section{Motives to Remit}

Among motives that drive remittances, the most basic distinction is between altruistic motives and those driven by self-interest. Whereas altruistic motives are not linked to any past contracts or expectations related to personal gain, the self-interest motive implies an exchange in which remittances are a resource belonging to the remitter that is exchanged for goods and services that provide utility to the remitter. A more detailed classification of motives includes altruism, 
exchange, inheritance, strategic motive, insurance, and investment. ${ }^{3}$ The relationship between these motives and possible responses of remittances to changes in remittances-recipient (home) country GDP and origin (host) GDP are presented in table 1.

Altruistic. If the motivations are altruistic, remittances would increase when the receiving economy is in a downturn and vice versa. This would imply a negative relationship between remittances and recipient economy GDP resulting in countercyclicality. Higher GDP in the origin country is likely to increase altruistic remittances, as well as those driven by exchange, inheritance, and insurance, resulting in procyclicality.

Exchange. The exchange motive implies that remittances "purchase" certain services like taking care of property or relatives (elders or children). Improvements in the recipient country's economy could increase the price of services and the returns the recipients could get from activities other than that mandated by the sender. This would lead to procyclicality with regard to the recipient economy.

Inheritance. The migration and remittances process is viewed as an arrangement that involves an informal contract whereby the family finances the migrant with the understanding that a future remittances stream will accrue to them. Potential inheritances act as an enforcement device to ensure that migrants do not renege on their promise or encourages them to send higher amounts in the hope of receiving a favorable share of the bequest (Hoddinot 1994). In this case higher GDP in the recipient country increases the value of the bequest and prompts more remittances. This would again lead to procyclicality.

Insurance. Because of the absence of means to cover risks arising from variability of income and employment in their home countries (such as unemployment insurance), members of a household migrate to a labor market not correlated with the home country. The migrant and the members left behind enter into an arrangement whereby the former sends remittances to cope with hard times while the latter pay for costs of migration. ${ }^{4}$ The insurance motive leads to countercyclicality since an adverse shock in the recipient country is compensated for by remittances.

Investment. The investment motive implies that families send migrants to increase the family's income. In this case, remittances are a return on the deployment of human capital. The family members then act as agents managing the funds on behalf of the remitter and this becomes similar to the exchange model. If investment is the motive, improved economic circumstances in the recipient country would increase remittances, leading to procyclicality.

3. See Rapoport and Docquier (2006) for a comprehensive survey.

4. Amuedo-Dorantes and Pozo (2006) find evidence of the opposite arrangement whereby the family provides insurance to the remitter. 
The cyclical response to changes in sending-country GDP may be indeterminate in the case of insurance- or investment-driven remittances. If migrants retain income opportunities in a downturn, remittances under both motives may increase. This outcome is more likely if returns on assets in the origin country are lower than in the recipient economy. This would lead to countercyclicality with respect to the sending country's GDP. ${ }^{5}$ However, if the migrant loses income opportunities in the origin country because of the downturn, remittances would be procyclical with respect to its GDP.

Strategic motive. The strategic motive arises from a view that prospective employers may not be able to initially ascertain the productivity of immigrant workers and consequently pay them according to the average productivity of their migrant community or country group. This circumstance induces higher-productivity migrants to send remittances as "bribes" to lowerproductivity potential migrants to encourage them to stay in the home country. In this case, decreased income opportunities at home may increase the propensity of those left behind to migrate, so more remittances may have to be sent to compensate them. This would imply countercyclicality with respect to the recipient country's GDP.

\section{Data}

The sample comprises observations primarily from the World Bank's World Development Indicators. The data are unbalanced and cover the period 1980-2012 for 109 countries. Table A.1 in appendix A provides a list of all variables used, together with the source for each variable. The data include 27 advanced economies, 28 emerging market economies, and 54 other developing economies. Remittances include personal transfers and compensation of employees, which are both items in the balance of payments (BPM6) framework. A large number of emerging and developing markets - the Remittance and Capital Flow Intensive countries (RCI group) - have received substantial inflows of capital as well as remittances during the 2003-2012 period. The RCI group includes countries that have, on average, experienced ratios of remittances to GDP higher than 1 percent during 2003-2012 period and either FDI inflows greater than 3.5 percent or equity inflows greater than 1 percent of GDP, on average, during the same period (the cutoffs correspond to median values for the full sample).

Remittances as a percentage of GDP are comparable to FDI flows and higher than portfolio equity inflows. For developing economies and RCI countries, remittances surpass FDI and ODA flows (Figure 2). Summary statistics are provided in table 2. For developing economies remittances, on

5. There can also be mixed motives. More complex theoretical formulations encompass merit goods whereby the remittances recipient renders nonmarket services (Chami el al. 2008). 
average, amount to close to 80 percent of reserves and for a large number of countries, remittances constitute the single largest source of foreign exchange. ${ }^{6}$

\section{Cyclical Features of Remittances}

As remittances continue to increase, economists' and policy makers' interest in this type of foreign currency flow is not only due to their size, but also to their stability over time in comparison with other foreign currency flows. The empirical evidence on how remittances react to business cycle fluctuations in the recipient country, however, remains inconclusive. ${ }^{7}$

This section revisits the question of how remittances behave during business cycle fluctuations and other large macroeconomic shocks. The analysis is carried out in several steps. First, the comovement of remittances inflows with GDP is analyzed. Second, remittances' co-movement with other foreign currency flows is examined, along with how they differ in volatility. Third, the behavior of remittances during sharp current account reversals, and banking, currency, and debt crises, is studied.

\section{Behavior of Remittances over the Business Cycle}

When analyzing the time series properties of variables in macroeconomics, it is common practice to detrend the series by using different filters. The filters eliminate both the long-term trend and any rapidly varying or irregular components, leaving behind only the business cycle variation of the series. Cyclicality is defined here as the correlation between the detrended series of GDP and the relevant flow. Each time series is decomposed into trend and cyclical components using a Hodrick-Prescott filter for the period 1980-2012. Following Ravn and Uhlig (2002) a smoothing parameter of 6.25 is used for annual data. The robustness of the main findings are checked with the Baxter-King filter, which yields similar results.

Foreign currency inflows are classified as (1) procyclical if the correlation between output and the cyclical component of flows is positive and statistically different from zero; (2) countercyclical if it is negative and statistically different from zero; and (3) acyclical if the correlation is not statistically different from zero. ${ }^{8}$ Panel a of figure 3 summarizes these correlations for various

6. For example, remittances as a percentage of GDP are high for Tajikistan (42 percent), the Kyrgyz Republic (32 percent), Nepal (29 percent), Moldova (25 percent), Haiti (21 percent), and many other countries. They are large as a percentage of exports for Tajikistan (467 percent), Nepal (418 percent), and Haiti (229 percent), among others. Remittances as a percentage of reserves are high for Tajikistan (542 percent), Pakistan (191 percent), El Salvador (144 percent), Egypt (108 percent), Honduras (104 percent), and the Kyrgyz Republic (102 percent), among others.

7. With respect to migrants' host countries, Bettin, Lucchetti, and Zazzaro (2012) find that positive shocks to host-country GDP are likely to translate into larger remittances.

8. The methodology follows the business cycle literature, and it has been used previously in Kydland and Prescott (1990) and Pallage and Robe (2001). 
country groups, showing that remittances are acyclical in approximately 80 percent of countries (this holds across country groups). At the same time, on average, remittances are less correlated with the business cycle than FDI and total inflows (panel b of figure 3 ).

Remittances are not strongly correlated with capital flows either (panel c of figure 3). More detailed information about these correlations can be found in table 3. Across different groups, remittances are weakly correlated with portfolio equity flows, total inflows, ODA, and net exports. They do appear to be more strongly correlated with FDI, although not so much so in emerging markets (correlation is zero). Overall, remittances appear to be a more stable (less volatile) source of external resources than financial inflows, including ODA (panel d of figure 3). ${ }^{9}$

Table 4 shows the proportion of countries that exhibit countercyclical and procyclical foreign currency flows for each country group (the remaining countries exhibit acyclical flows). Remittances are procyclical in 14.7 percent of the countries, compared with 39.3 for FDI and 48.2 for total inflows. They appear not to co-move with output in about 78 percent of countries. One further observation from table 4 is that remittances seem to be considerably more procyclical for high-remittances countries and RCI countries (20.0 and 31.2, respectively), suggesting that in several countries in those groups, remittances are more prone to exacerbate business cycle movements in the recipient economy.

How do these results compare with other studies that use cross-country data? As mentioned in the introduction, some studies find that remittances are negatively correlated with output fluctuations in the recipient economies (Frankel 2011; Bettin, Presbitero, and Spatafora 2015). ${ }^{10}$ In contrast, other studies find that remittances are positively correlated with income in the recipient countries (Giuliano and Ruiz-Arranz 2009; Sayan 2006; Cooray and Mallick 2013). Ruiz and Vargas-Silva (2014) argue that cyclicality of remittances with respect to the receiving economy can be country or corridor specific. To answer the question of cyclicality of remittances, this analysis uses the most up-to-date remittances data for a large sample of countries and a robust methodology to

9. The results are broadly similar when volatility is defined as the coefficient of variation (standard deviation of the series over the sample period normalized by the mean of the corresponding flow). These findings are also in line with previous studies in the literature, including Chami et al. (2008) and Constantinescu and Schiff (2014).

10. Other studies include Singh et al. (2011); Combes et al. (2014); Bugamelli and Paterno (2011); Chami, Hakura, and Montiel (2012); and many others. The studies vary significantly in the data they use, sample coverage, and methodology. Some of these studies focus on single countries or regions. Bettin, Presbitero, and Spatafora (2015) study remittances from Italian provinces to developing countries. Studies focusing on earlier time periods are more susceptible to measurement issues in remittances data (see Clemens and McKenzie 2014). 
define cyclicality. The findings show that remittances are acyclical, with some variations across countries. ${ }^{11}$

As a further robustness check, the cyclicality of remittances is calculated following different methodologies used in previous work that studies business cycle properties of foreign currency flows. The results are shown in table 5. Broner et al. (2013) look at the correlations between growth of real GDP and the de-meaned financial flow that is normalized by dividing by trend GDP. The results from this method are similar in magnitude to the previous results of this analysis, confirming the main findings. ${ }^{12}$ Another important study, Kaminsky, Reinhart, and Végh (2005), uses the cyclical component of real GDP and the nominal value of capital flows to establish the cyclicality of financial flows. The present paper finds higher correlations for each country group (and a higher percentage of procyclical countries). This outcome is not unexpected, because inherently prices may be correlated with GDP and this method would produce higher correlations. $^{13}$

Chami et al. (2008) calculate the correlations between the cyclical component of real GDP and remittances divided by GDP. By construction, the two variables are expected to be negatively correlated. The present exercise finds, on average, low negative correlations, similar to those reported by Chami et al. (2008). This correlation would be interesting if it suggested procyclicality or acyclicality and should be of no surprise if the result is negative (column 4 of table 5). A similar argument can be made when using the Pallage and Robe (2001) methodology, in which the authors divide the flow (of aid) by the import price deflator. Our calculations show that import prices are positively correlated with GDP, and by construction, the results would be biased toward negative correlations.

To sum up, capital flows such as FDI and debt flows are often procyclical. As such, they can exacerbate output fluctuations and contribute to the volatility of consumption in developing countries when abruptly leaving the country. ${ }^{14}$ Although remittances are not necessarily countercyclical, their acyclicality suggests that they have the potential to at least provide some stability for the balance of payments, and hence for the economy more generally, when capital

11. This heterogeneity strengthens the argument that the effects of remittances on the macroeconomy should be evaluated in a general equilibrium framework that takes into account country-specific conditions, as in Durdu and Sayan (2010).

12. We believe that this method is more suitable if the series were to be used in cross-country regressions, which is what Broner et al. (2013) do.

13. Despite the inherent bias toward a positive correlation, only 38.5 percent of the countries exhibit procyclical behavior of remittances, and in about 55 percent of the sample remittances appear to be acyclical (third column in table 5).

14. Kaminsky, Reinhart, and Végh (2005) show that capital flows are highly procyclical. Contessi, De Pace, and Francis (2013) document that the components of inward capital flows are also procyclical for the group of G7 economies. Islamaj (2014) reports that capital flows may increase the volatility of output by increasing specialization. 
inflows decline. The next section examines whether these broad trends about the relative stability of remittances are preserved during periods of sharp macroeconomic volatility.

\section{Behavior of Remittances during Periods of Large Macroeconomic Shocks}

The resilience of remittances during business cycle fluctuations is one argument for supporting the stabilizing role that they may bring to emerging market and developing economies. However, the cycles in emerging market and developing economies are often exacerbated by sharp capital flow reversals and financial crises, including banking, currency, and sovereign debt crises. How do remittances behave during these major episodes of macroeconomic and financial volatility?

To answer this question the behavior of remittances during sudden stops and financial crises is analyzed. A sudden stop, defined as a sharp decrease in gross capital inflows, is often associated with increased risk of macroeconomic volatility and financial crises in emerging market and developing economies. The timing of sudden stops can be identified using a variety of methodologies. This exercise follows the methodology of Forbes and Warnock (2012) and identifies a large number of sudden stops over during the period 1990-2012. Table A.2 in appendix A provides a complete list of sudden-stop episodes.

The global financial crisis starting in 2008 saw a plethora of sudden stops in capital inflows. In contrast, remittances showed slight above-trend growth during the financial crisis (figure 4). The same pattern is observed during previous, less severe and less synchronized crisis episodes, with remittances generally displaying resilience, while capital inflows gyrate. The results are similar for other country groupings, including for emerging markets and RCI economies taken separately (table 6).

Whereas capital flows, on average, decline about 14.8 percent during the initial year of a sudden stop episode and continue to fall by another 10 percent the following year, remittances tend to increase by 6.6 percent during the first year and another 5.7 percent in the subsequent year. Moreover, remittances are resilient in emerging markets and RCI economies taken separately, even though the decline in capital inflows for these country groups is often sharper than for other groups. During the first year of a sudden stop, capital inflows to emerging markets fall 25.2 percent, on average, whereas remittances increase by 6.8 percent (table 7).

Remittances also show resilience during financial crises. This report uses data on crises from Laeven and Valencia (2013) and compares the behavior of remittances during these crises to that of capital inflows for various country subsamples. Although capital inflows have been feeble, remittances continue to be stable during such crises. Compared with two years before a crisis starts, total capital inflows fall, on average, by as much as 65 percent two years after the onset of a currency crises, whereas remittances appear to be 15 percent higher. The difference is even starker for banking crises, with capital inflows falling as much as 83 percent, whereas remittances increase 
by 24 percent. For any crisis, two years after the onset remittances increase, on average, by 18 percent compared with two years before the crisis, whereas total inflows fall by as much as 80 percent during the same period (see tables $8-10$ for details). These results broadly speak to a supportive role for remittances during periods of large macroeconomic shocks.

\section{Remittances and Consumption Stability}

The ability to reduce fluctuations in consumption is an important determinant of economic welfare. Capital flows in the form of short-term foreign borrowing or sales of foreign liquid assets might be used to finance consumption during bad times. Provided that fluctuations in income are not fully synchronized across countries, and financial markets are operating effectively, output uncertainty can be shared across borders through capital flows, thus lowering consumption dependence on domestic output fluctuations.

Not surprisingly, there has been a growing literature studying the effects of financial flows on consumption stability at the macro level. This literature finds only minimal impact of equity flows on consumption smoothing in developing countries. Although the relative stability of remittances over the business cycle suggests that large-scale recipients may be less prone to consumption volatility, the literature devotes little to the stabilizing effects of remittances on consumption fluctuations. ${ }^{15}$ To estimate the quantitative effect, this analysis follows a standard approach in the risk-sharing literature and considers the impact of remittances on the co-movement between domestic consumption and output. ${ }^{16}$ In particular, we regress country-specific consumption growth on country-specific output growth:

$$
\Delta c_{i t}-\Delta \overline{c_{t}}=\beta_{0}+\gamma_{1} R_{i t}+\beta_{1}\left(\Delta y_{i t}-\Delta \overline{y_{t}}\right)+\beta_{2} R_{i t}\left(\Delta y_{i t}-\Delta \overline{y_{t}}\right)+\Delta \varepsilon_{i t}
$$

in which, $\Delta c_{i t}\left(\Delta \overline{c_{t}}\right)$ is country (world) consumption growth at time $t ; \Delta y_{i t}\left(\Delta \overline{y_{t}}\right)$ is country (world) GDP growth at time $t$; and $R_{i t}$ is remittances inflows as a ratio to GDP at time $t$. The coefficient $\beta_{1}$ estimates the extent to which domestic consumption growth is dependent on output fluctuations. An interaction term between remittances and output growth is added to the regression, and measures the extent to which remittances flows help delink domestic consumption from domestic output growth. A negative $\beta_{2}$ would suggest that remittances help lower the correlation

15. Jidoud (2015) investigates the effect of remittances on output and consumption growth volatility in a cross-section of African economies. Although he finds that remittances reduce the volatility of output growth, the coefficient on consumption growth is insignificant. These results are consistent with Bugamelli and Paterno (2009) and Chami, Hakura, and Montiel (2012). Jidoud (2015) also uses a decomposition approach and finds that remittances contribute to income-risk-sharing.

16. Seminal contributions include Lewis (1996) and Obstfeld (1994). Kose, Prasad, and Terrones (2009) provide a review of the literature. 
between country-specific consumption and output growth. All regressions include time and country fixed effects.

Fixed effects panel ordinary least squares estimates of the interaction coefficient $\beta_{2}$ for different country groups are presented in figure 5 . Estimated $\beta_{2}$ is negative and statistically significant for all country groups. The coefficient for RCI countries and for countries with large remittances inflows is even higher (in absolute value) than those for the other groups, suggesting that countries that receive a larger amount of remittances have, on average, a lower correlation between own output and consumption growth. These findings imply relatively larger benefits of remittances for consumption stability in countries that have (1) sizable remittances receipts, as well as (2) high exposure to interruptions in capital flows.

The stabilizing effect of remittances may also depend on the exchange rate system. During sudden stops and recessions, flexible exchange rates tend to depreciate. Given that remittances in terms of U.S. dollars are relatively stable, the value of remittances in local currencies then tends to increase, thereby acting as an automatic stabilizer for the purchasing power of consumers. In fact, the stabilizing effects of remittances on consumption tend to be much more pronounced under flexible exchange rate regimes.

The results presented in figure 5 hold for various country groups. De jure and de facto measures of financial openness are also controlled for following the previous literature on risk sharing (table 11). As mentioned, output risks can be shared internationally by purchasing assets across borders. The degree of risk sharing will depend on the extent of the financial globalization of each country with the rest of the world. Financial globalization can be captured by (1) the ability of each country to trade foreign shares without restrictions (as represented by a de jure measure of financial openness) and (2) by the extent of cross-border financial flows (a de facto measure of financial integration).

The de jure financial openness index comes from Chinn and Ito (2006). The data cover 19702012, measuring restrictions on cross-border financial transactions reported in the IMF's Annual Report on Exchange Arrangements and Exchange Restrictions. De facto measures of financial integration are represented by FDI and portfolio equity flows from Lane and Milesi-Ferretti's (2007) capital flows data set. Both de jure and de facto measures are interacted with countryspecific output growth and are added as controls to the linear regression described above in the order shown in each column of table 11.

Column 1 of table 11 shows the baseline regression. The coefficient of regressing country-specific output growth on country-specific consumption growth is positive, statistically significant, and smaller than 1, consistent with previous studies (Lewis 1996; Obstfeld 1994). The coefficient $\beta_{2}$ corresponding to the first bar in figure 5 can be tracked in the second column of table 11. It is negative, statistically significant, and high in magnitude compared with the coefficient of de jure 
financial openness in the third column, suggesting remittances help improve consumption smoothing.

Columns $4-8$ of table 11 show the coefficient $\beta_{2}$ while controlling for financial openness measures. The coefficient $\beta_{2}$ continues to be significant and high in magnitude. However, de jure and de facto measures of financial integration appear to not be statistically significantly correlated with consumption smoothing. The results hold across country groups. They are consistent with previous literature that has not been able to find robust evidence that financial openness improves consumption smoothing using linear regression models (Kose, Prasad, and Terrones 2009).

Through which channels can remittances help stabilize consumption? First, remittances can help stabilize consumption intertemporally by supporting saving. Some studies based on microeconomic data document that remittances are an important resource that enable households to smooth consumption over time because they help improve access to financial services and ease liquidity constraints. ${ }^{17}$ Second, even if overall remittances do not increase substantially during economic downturns, a greater proportion of remittances receipts is likely to be used for consumption purposes during such periods. Given that remittances, unlike capital flows, are unrequited transfers that do not have to be paid back and target the portion of consumers that are more likely to be liquidity constrained, they may have substantial effects on consumption stability.

In addition, at the individual level, access to remittances enables consumers to maintain their consumption levels despite illness or other calamity, which may be critical at very low levels of income. Some studies find that remittances support household consumption following natural disasters or other economic shocks. For example, Yang and Choi (2007) find that overseas remittances serve almost like insurance following rainfall shocks in the Philippines. Analysis of household survey data shows that Ethiopian households that receive international remittances seem to rely more on cash reserves and less on selling household assets or livestock to cope with drought (Mohapatra, Joseph, and Ratha 2012).

\section{Conclusions}

This paper analyzes the potential of remittances flows to act as a stabilizer during episodes of high macroeconomic volatility. The analysis is carried out in four steps. First, the cyclical properties of

17. Islamaj and Kose (forthcoming) provide a discussion on how the easing of liquidity constraints is associated with better intertemporal consumption-smoothing outcomes. World Bank (2006); Adams and Cuecuecha (2013); Giuliano and Ruiz-Arranz (2009); and Aga and Martinez-Peria (2014) document that remittances improve financial inclusion for poor households by increasing access to savings, bank deposits, and bank credit. The findings in this report also complement others reported in the literature. For example, Craigwell, Jackman, and Moore (2010) find that remittances reduce the impact of negative output shocks. Bugamelli and Paterno (2011) and Acosta et al. (2008) report that remittances are negatively correlated with output volatility. IMF (2005) also finds that remittances are associated with lower volatility of output, consumption, and investment. 
remittances in theory are studied. The review of theory shows that these properties are closely related to the motives that drive remittances. Remittances are driven by either altruistic motives or self-interest. In the former case they usually tend to be countercyclical. In the latter case, they are largely procyclical.

Second, the evidence on the cyclicality of remittances over the business cycle is reviewed for a sample of 109 advanced, emerging market, and developing countries for the period 1980-2012. Third, the behavior of remittances flows during episodes of significant macroeconomic volatility, such as current account reversals and financial crises, is analyzed. Fourth, cross-country regressions are used to investigate the role of remittances flows in smoothing consumption over time.

The report finds that remittances are relatively stable and acyclical. In contrast, debt flows and FDI are procyclical. Stability and acyclicality imply that remittances have the potential to make a critical contribution in supporting consumption in the face of economic adversity. This finding is particularly important in developing countries, where remittances are used to finance household consumption directly.

In addition, remittances have been stable during episodes of financial volatility, including sudden stops and financial crises. Remittances are also associated with smoother domestic consumption growth. Countries with large remittances receipts tend to display less correlation between output and consumption growth over the business cycle than countries with small remittances receipts. Such consumption-smoothing behavior could enhance welfare.

The results reveal certain subtleties of the data that may be helpful to examine in future research. First, there is a considerable degree of heterogeneity in the cyclicality of remittances across countries. Future research needs to investigate the sources of these differences and seek to identify the conditions under which remittances help lower macroeconomic volatility. Second, these heterogeneities have implications for the theoretical literature. In particular, models that take into account remittances flows should be of a general equilibrium nature and need to control for country-specific characteristics. 


\section{References}

Acosta, P. A., C. Calderon, P. Fajnzylber, and J. H. Lopez. 2008. "Do Remittances Lower Poverty Levels in Latin America?" In Remittances and Development: Lessons from Latin America, edited by P. Fajnzylber and J. H. Lopez. Washington, DC: World Bank.

Adams Jr, R. H., and A. Cuecuecha. 2013. "The Impact of Remittances on Investment and Poverty in Ghana.” World Development 50: 24-40.

Aga, G. A., and M. S. Martinez Peria. 2014. "International Remittances and Financial Inclusion in Sub-Saharan Africa.” World Bank Policy Research Working Paper No. 6991, World Bank, Washington, DC.

Amuedo-Dorantes, C., and S. Pozo. 2006. "Remittance as Insurance: Evidence from Mexican Immigrants.” Journal of Population Economics 19 (2): 227-54.

—. 2011. "Remittances and Income Smoothing." American Economic Review 101 (3): $582-$ 87.

Balli, F., and H. O. Balli. 2011. "Income and Consumption Smoothing and Welfare Gains across Pacific Island Countries: The Role of Remittances and Foreign Aid." Economic Modelling 28 (4): 1642-49.

Bettin, G., R. Lucchetti, and A. Zazzaro. 2012. "Endogeneity and Sample Selection in a Model for Remittances.” Journal of Development Economics 99 (2): 370-84.

Bettin, G., A. Presbitero, and N. Spatafora. 2015. "Remittances and Vulnerability in Developing Countries.” World Bank Economic Review September 29, 1-29.

Broner, Fernando, Tatiana Didier, Aitor Erce, and Sergio Schmukler. 2013. "Gross Capital Flows: Dynamics and Crises." Journal of Monetary Economics 60 (1): 113-33.

Bugamelli, M., and F. Paterno. 2009. 'Do Workers' Remittances Reduce the Probability of Current Account Reversals?” World Development 37 (12): 1821-38.

—. 2011. "Output Growth Volatility and Remittances.” Economica 78 (311): 480-500.

Chami, R., A. Barajas, T. Cosimano, C. Fullenkamp, M. Gapen, and P. Montiel. 2008. "Macroeconomic Consequences of Remittances." IMF Occasional Paper 259, International Monetary Fund, Washington, DC.

Chami, R., D. Hakura, and P. Montiel. 2012. "Do Worker Remittances Reduce Output Volatility in Developing Countries?” Journal of Globalization and Development 3 (1): 1-25.

Chinn, Menzie D., and Hiro Ito. 2006. "What Matters for Financial Development? Capital Controls, Institutions, and Interactions.” Journal of Development Economics 81 (1): 163-92. 
Clemens, M. A., and D. McKenzie. 2014. "Why Don't Remittances Appear to Affect Growth?" World Bank Policy Research Working Paper 6856, World Bank, Washington, DC.

Combes, J.-L., C. Ebeke, M. N. Etoundi, and T. Yogo. 2014. "Are Foreign Aid and Remittance Inflows a Hedge against Food Price Shocks in Developing Countries?” World Development 54 (1): 81-98.

Constantinescu, I. C., and M. Schiff. 2014. "Remittances, FDI and ODA: Stability, Cyclicality and Stabilizing Impact in Developing Countries." International Journal of Migration and Residential Mobility 1 (1): 84-106.

Cooray, A., and D. Mallick. 2013. "International Business Cycles and Remittance Flows." BE Journal of Macroeconomics 13 (1): 1-33.

Contessi, S., P. De Pace, and J. L. Francis. 2013. “The Cyclical Properties of Disaggregated Capital Flows." Journal of International Money and Finance 32 (February): 528-55.

Craigwell, R., M. Jackman, and W. Moore. 2010. "Economic Volatility and Remittances." International Journal of Development Issues 9 (1): 25-42.

Durdu, C. B., and S. Sayan. 2010. "Emerging Market Business Cycles with Remittance Fluctuations." IMF Staff Papers 57 (2): 303-25.

Forbes, K. J., and F. E. Warnock. 2012. "Capital Flow Waves: Surges, Stops, Flight, and Retrenchment." Journal of International Economics 88 (2): 235-51.

Frankel, J. 2011. “Are Bilateral Remittances Counter-Cyclical?” Open Economy Review 22: 1-16.

Giuliano, P., and M. Ruiz-Arranz. 2009. "Remittances, Financial Development, and Growth." Journal of Development Economics 90 (1): 144-52.

Hoddinot, John. 1994. "A Model of Migration and Remittances Applied to Western Kenya." Oxford Economic Papers 46 (3): 459-76.

Ilzetzki, E., C. Reinhart, and K. Rogoff. 2008. "The Country Chronologies and Background Material to Exchange Rate Arrangements in the 21st Century: Which Anchor Will Hold." Working Paper.

International Monetary Fund. 2005. World Economic Outlook, April, Washington, DC.

Islamaj, E. 2014. "Industrial Specialization, Financial Integration and International Consumption Risk Sharing." BE Journal of Macroeconomics 14 (1): 33.

, and M. A. Kose. Forthcoming. "How Does the Sensitivity of Consumption to Income Vary over Time? International Evidence." World Bank Working Paper, Washington.

Jidoud, A. 2015. "Remittances and Macroeconomic Volatility in African Countries." IMF Working Paper 15/49, International Monetary Fund, Washington. 
Kaminsky, G. L., C. M. Reinhart, and C. A. Végh. 2005. "When It Rains, It Pours: Procyclical Capital Flows and Macroeconomic Policies." In NBER Macroeconomics Annual 2004, Volume 19, 11-82. Cambridge, MA: MIT Press.

Kose, Ayhan M., Eswar S. Prasad, and Marco E. Terrones. 2009. "Does Financial Globalization Promote Risk Sharing?” Journal of Development Economics 89 (2): 258-70.

Kydland, F. E., and E. C. Prescott. 1990. "Business Cycles: Real Facts and a Monetary Myth." Federal Reserve Bank of Minneapolis Quarterly Review 14: 3-18.

Laeven, Luc, and Fabian Valencia. 2013. "Systemic Banking Crises Database." IMF Economic Review 61 (2): 225-70.

Lane, Philip R., and Gian Maria Milesi-Ferretti. 2007. "The External Wealth of Nations Mark II: Revised and Extended Estimates of Foreign Assets and Liabilities, 1970-2004." Journal of International Economics 73 (November): 223-50.

Lewis, Karen K. 1996. "What Can Explain the Apparent Lack of International Consumption Risk Sharing?” Journal of Political Economy 104 (2): 267-97.

Lucas, Robert E. B., and Oded Stark. 1985. "Motivations to Remit: Evidence from Botswana." Journal of Political Economy 93 (5): 901-18.

Lueth, Erik, and Marta Ruiz-Arranz. 2008. "Determinants of Bilateral Remittance Flows." BE Journal of Macroeconomics 8 (1).

Mohapatra, Sanket, George Joseph, and Dilip Ratha. 2012. "Remittances and Natural Disasters: Ex-Post Response and Contribution to Ex-Ante Preparedness." Environment, Development and Sustainability 14 (3): 365-87.

Obstfeld, Maurice. 1994. “Are Industrial-Country Consumption Risks Globally Diversified?” In Capital Mobility: The Impact of Consumption, Investment and Growth, edited by L. Leiderman and A. Razin, 13-47. New York; Cambridge University Press.

Pallage, S., and M. A. Robe. 2001. "Foreign Aid and Business Cycle." Review of International Economics 9 (4): 641-72.

Rapoport, H., and F. Docquier. 2006. “The Economics of Migrants' Remittances.” In Handbook on the Economics of Giving, Altruism and Reciprocity, vol. 2, edited by S. Kolm and J. Mercier Ythier, 1135-98. Amsterdam: North Holland

Ravn, M., and H. Uhlig. 2002. "On Adjusting the HP-Filter for the Frequency of Observations." Review of Economics and Statistics 84 (2): 371-76.

Ruiz, I., and C. Vargas-Silva. 2014. "Remittances and the Business Cycle: A Reliable Relationship?” Journal of Ethnic and Migration Studies 40 (3): 456-74. 
Sayan, S. 2006. "Business Cycles and Worker's Remittances: How Do Migrant Workers Respond to Cyclical Movements of GDP at Home?" IMF Working Paper 06/52, International Monetary Fund, Washington, DC.

Singh, Raju Jan, Markus Haacker, Kyung-woo Lee, and Maëlan Le Goff. 2011. "Determinants and Macroeconomic Impact of Remittances in Sub-Saharan Africa." Journal of African Economies 20 (2): 312-40.

World Bank. 2006. Global Economic Prospects, Economic Implications of Remittances and Migration. Washington, DC: World Bank.

Yang, D., and H. Choi. 2007. "Are Remittances Insurance? Evidence from Rainfall Shocks in the Philippines." World Bank Economic Review 21 (2): 219-48. 
Figure 1 Remittances and Other Flows to

Developing Countries

(Billions of current US\$)

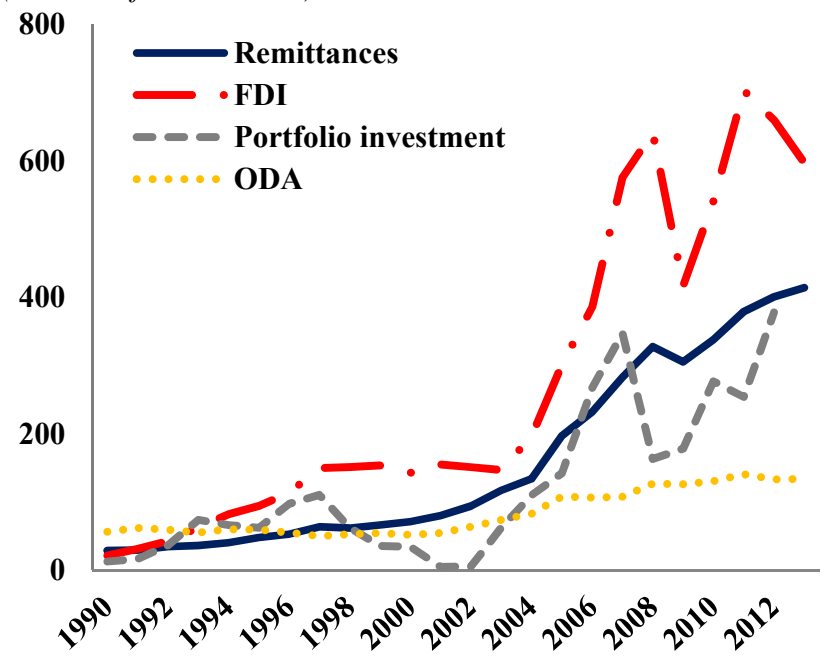

Sources: Data from World Bank World Development Indicators and IMF Balance of Payments.

Note: Remittances are based on IMF Balance of Payments Accounts; FDI $=$ foreign direct investment, net inflows; Portfolio investment $=$ private debt and portfolio equity; ODA = net official development assistance and official aid received.
Figure 2 Remittances and Other Flows across Country Groups (\% of GDP)

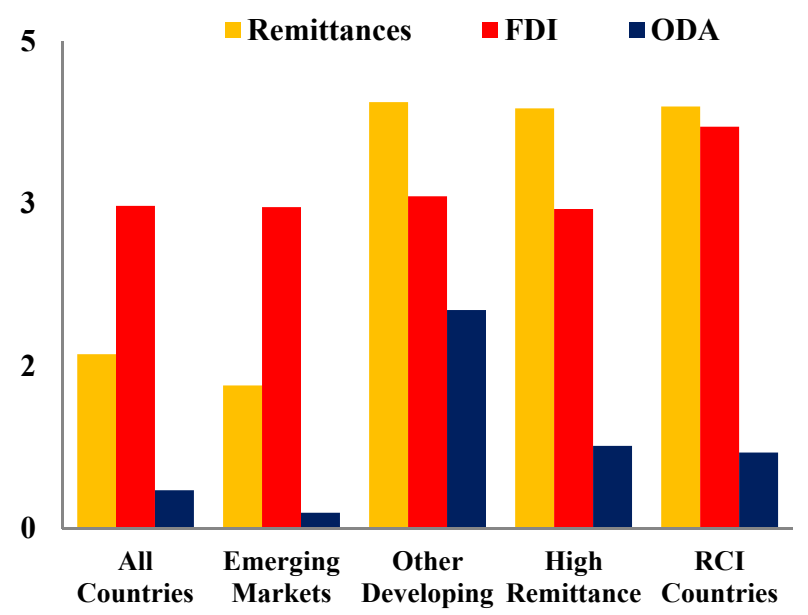

Sources: Data from World Bank World Development Indicators and IMF Balance of Payments.

Note: "All countries" includes all countries in the sample. "High remittance" refers to a set of countries for which remittances have been greater than 1 percent of GDP during the 2003-12 period. "RCI [Remittance and Capital Flow Intensive] countries" refers to a set of countries for which remittances and remittances plus either FDI or equity flows have been greater than the median (1 percent of GDP, 3.5 percent of GDP, and 1 percent of GDP, respectively) during the 2003-12 period. FDI = foreign direct investment; ODA = official development assistance and aid. The sample period is 200312 . 
Figure 3 Cyclical Properties of Remittances

a. Remittances and Business Cycles ${ }^{\mathbf{a}, \mathbf{b}}$

(\% of countries)

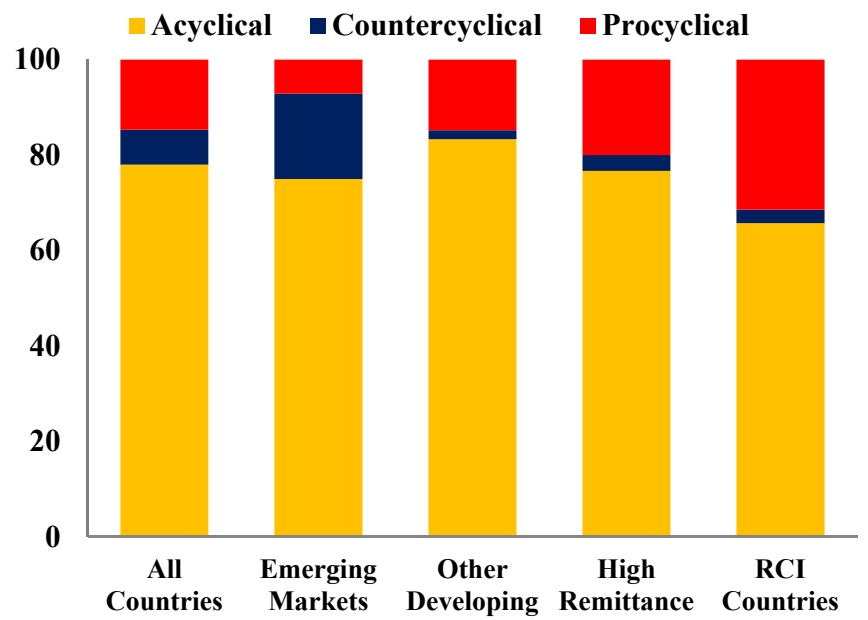

b. Correlation of Remittances with GDP' (Median)

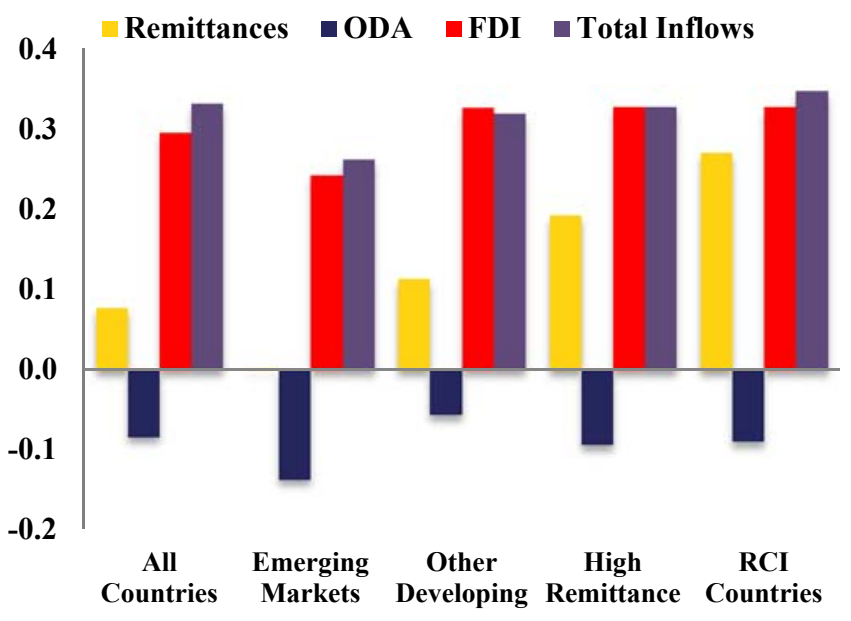

\section{c. Remittances and Capital Inflows (\% of countries)}

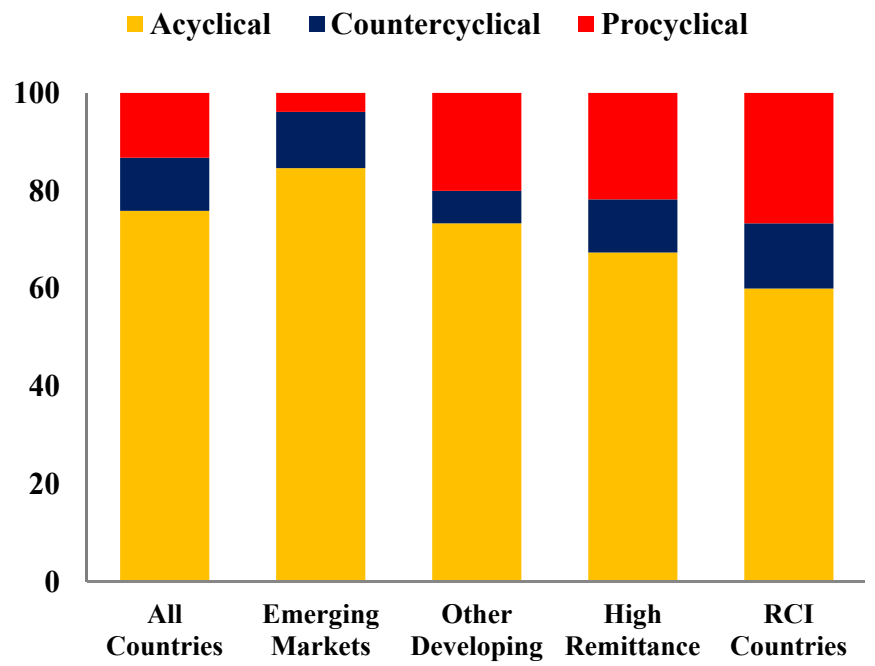

\section{d. Volatility of Inflows}

(Mean standard deviation)

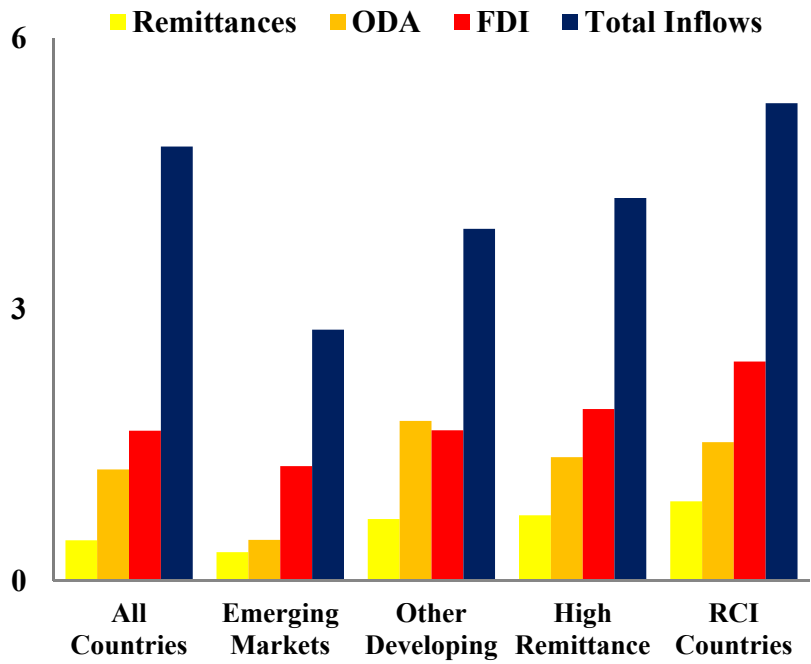

Source: Authors' estimates.

Note:

a. Cyclicality is defined as the correlation between the detrended real series of GDP and foreign direct investment (FDI), official development assistance (ODA), and total inflows (the sum of FDI, portfolio investment [including equity and debt], financial derivatives, and other investments). Each series is decomposed into trend and cyclical components using a Hodrick-Prescott (HP) filter and the sample period is 1980-2012. See the note to figure 2 for definitions of the country groupings.

b. Remittances are considered procyclical if the correlation between the cyclical components of remittances and output is positive and statistically different from zero, countercyclical if it is negative and statistically different from zero, and acyclical if the correlation is not statistically different from zero.

c. Volatility is defined as the standard deviation of the detrended ratio of the relevant inflow to GDP. 
Figure 4 Remittances and Capital Inflows during Sudden Stops

(Index numbers)

a. 2008 crisis

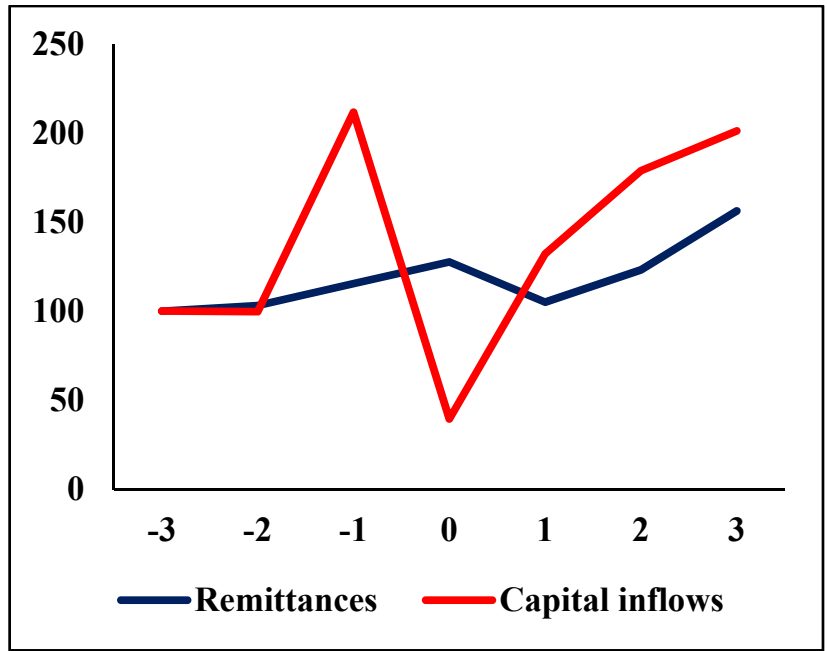

b. Crises other than 2008

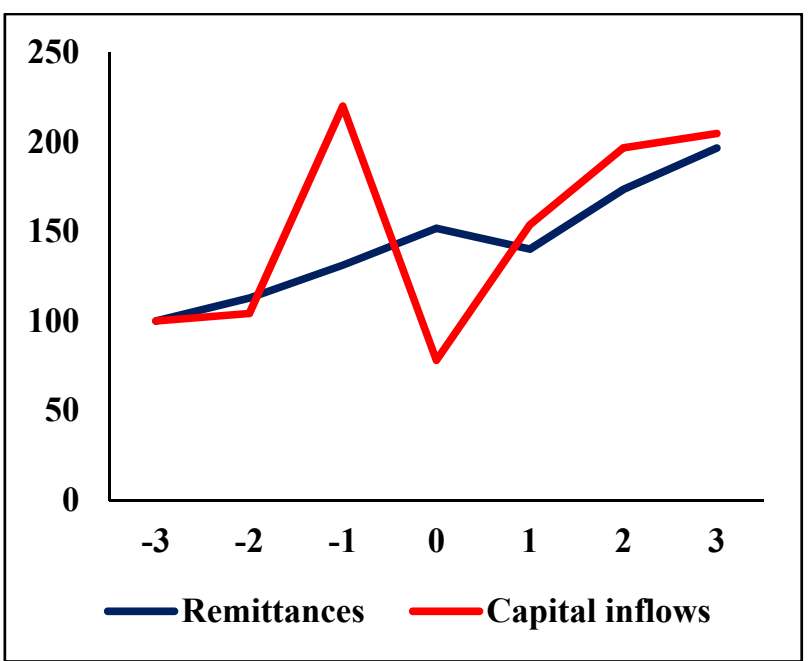

Source: Data from the World Bank World Development Indicators and Global Capital Flows; and authors' calculations. Note: Values are averages of remittances and net capital inflows for emerging market and developing economies that have experienced sudden stop episodes. Index numbers are calculated with a base of 100 for the period three years before the sudden stop year $(-3)$. Capital inflows are net, that is, the difference between the amounts brought in by nonresidents and the amounts sent out by residents. The horizontal axis denotes years. Zero (0) refers to the year of the sudden stop episode. 
Figure 5 Remittances and Consumption Stability

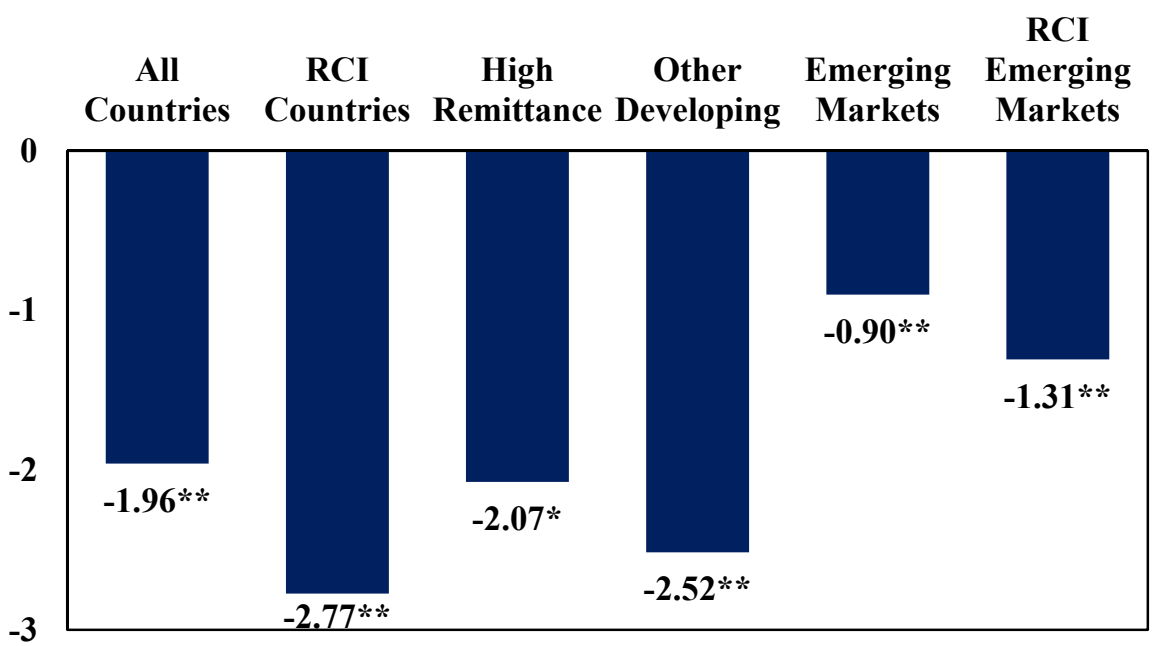

Source: Authors' estimates.

Note: The figure shows panel ordinary least squares estimates for the effect of remittances on consumption stability $\left(\beta_{2}\right)$. The symbols $*$ and $* *$ indicate statistical significance at the 10 percent and 5 percent levels, respectively. "High remittance" refers to a set of countries for which remittances have been above 1 percent during the 2003-12 period. See the note to figure 2 for definitions of the country groupings. 
Table 1 Response of Remittances to GDP Fluctuations in Origin and Recipient Economies

\begin{tabular}{|c|c|c|c|c|c|c|}
\hline & Altruistic & Exchange & Inheritance & Strategic & Insurance & Investment \\
\hline Recipient & $(-)$ & $(+)$ & $(+)$ & $(-)$ & $(--)$ & $(+)$ \\
\hline Origin & $(+)$ & $(+)$ & $(+)$ & $(+)$ & Indeterminate & Indeterminate \\
\hline
\end{tabular}

Note: $(-)$ refers to countercyclical; $(+)$ refers to procyclical. See section 2 for details.

Table 2 Summary Statistics: Remittances, Capital Flows, and Net Exports (Correlation coefficient)

\begin{tabular}{|c|c|c|c|c|c|c|}
\hline \multicolumn{7}{|c|}{ A: Full Sample } \\
\hline & Remittances & FDI & $\begin{array}{c}\text { Portfolio } \\
\text { equity }\end{array}$ & $\begin{array}{c}\text { Total } \\
\text { inflows } \\
\end{array}$ & $\begin{array}{c}\text { ODA and } \\
\text { aid } \\
\end{array}$ & $\begin{array}{c}\text { Net } \\
\text { exports }\end{array}$ \\
\hline Mean & 3.41 & 3.77 & 1.05 & 8.41 & 4.68 & -4.84 \\
\hline $\begin{array}{l}\text { (Standard } \\
\text { deviation) }\end{array}$ & $(5.45)$ & (3.18) & $(5.57)$ & $(8.43)$ & $(5.46)$ & $(10.19)$ \\
\hline Observations & 109 & 93 & 79 & 93 & 89 & 109 \\
\hline \multicolumn{7}{|c|}{ B: By Country Group } \\
\hline & Remittances & FDI & $\begin{array}{c}\text { Portfolio } \\
\text { equity }\end{array}$ & $\begin{array}{c}\text { Total } \\
\text { inflows } \\
\end{array}$ & $\begin{array}{l}\text { ODA and } \\
\text { aid } \\
\end{array}$ & $\begin{array}{c}\text { Net } \\
\text { exports }\end{array}$ \\
\hline Emerging markets & 2.53 & 2.63 & 0.37 & 4.36 & 1.44 & -1.25 \\
\hline Other economies & 5.18 & 4.73 & 0.32 & 8.54 & 6.87 & -9.03 \\
\hline High remittance & 5.79 & 4.49 & 0.29 & 7.97 & 5.27 & -9.50 \\
\hline RCI countries & 6.73 & 5.85 & 0.39 & 10.24 & 4.94 & -11.28 \\
\hline
\end{tabular}

Source: World Bank's World Development Indicators and Global Capital Flows.

Note: The table shows the summary statistics for the ratio of each flow to GDP during 1980-2012. Panel A provides summary statistics for the full sample and panel B reports averages across different country groups. FDI measures foreign direct investment. ODA covers official development assistance and aid, and Total inflows is the sum of FDI, portfolio investment (including equity and debt), financial derivatives, and other investments. See the note to figure 2 for definitions of the country groupings. 


\section{Table 3 Correlations with Output and Capital Flows}

(Correlation coefficient)

\begin{tabular}{l|cccccc}
\hline & \multicolumn{7}{|l}{ A: Correlation of each Flow with GDP } & & & \\
& Remittances & FDI & Portfolio equity & Total inflows & ODA and aid & Net exports \\
\hline \hline All countries & 0.08 & 0.30 & -0.01 & 0.33 & -0.08 & -0.27 \\
Emerging markets & 0.00 & 0.24 & 0.01 & 0.26 & -0.14 & -0.35 \\
Other economies & 0.11 & 0.33 & 0.10 & 0.32 & -0.06 & -0.15 \\
High remittance & 0.19 & 0.33 & 0.04 & 0.33 & -0.09 & -0.29 \\
RCI countries & 0.27 & 0.33 & 0.03 & 0.35 & -0.09 & -0.29 \\
\hline
\end{tabular}

B: Correlation of each Flow with Remittances

FDI Portfolio equity Total inflows ODA and aid Net exports

\begin{tabular}{lccccc}
\hline \hline All countries & 0.15 & -0.03 & 0.04 & 0.11 & -0.05 \\
Emerging markets & 0.00 & 0.01 & -0.03 & 0.12 & 0.10 \\
Other economies & 0.31 & 0.05 & 0.13 & 0.09 & -0.12 \\
High remittance & 0.31 & 0.02 & 0.08 & 0.09 & -0.08 \\
RCI countries & 0.38 & 0.07 & 0.12 & 0.01 & -0.13 \\
\hline
\end{tabular}

Source: Authors' estimates.

Note: Cyclicality is defined as the correlation between the detrended real series of GDP and the relevant inflow. Panel A provides the median correlation of each flow with GDP for each country grouping while panel B reports their median correlations with remittances. FDI measures foreign direct investment. ODA covers official development assistance and aid, and Total inflows is the sum of FDI, portfolio investment (including equity and debt), financial derivatives, and other investments. Each time series is decomposed into trend and cyclical components using a Hodrick-Prescott (HP) filter and the sample period is $1980-2012$. See the note to figure 2 for definitions of the country groupings. 


\section{Table 4 Cyclicality of Remittances, Capital Flows, and Net Exports}

(\% of countries)

\begin{tabular}{|c|c|c|c|c|c|c|c|}
\hline & & Remittances & FDI & Portfolio equity & Total inflows & ODA and aid & Net exports \\
\hline \multirow{3}{*}{$\begin{array}{l}\text { All } \\
\text { countries }\end{array}$} & $\%$ Countercyclical & 7.3 & 2.4 & 6.2 & 1.2 & 15.7 & 44.0 \\
\hline & \% Procyclical & 14.7 & 39.3 & 3.1 & 48.2 & 4.5 & 6.4 \\
\hline & Observations & 109 & 84 & 65 & 83 & 89 & 109 \\
\hline \multirow{3}{*}{$\begin{array}{l}\text { Emerging } \\
\text { markets }\end{array}$} & $\%$ Countercyclical & 17.9 & 7.4 & 4.2 & 3.8 & 25.0 & 50.0 \\
\hline & $\%$ Procyclical & 7.1 & 37.0 & 0.0 & 38.5 & 3.6 & 3.6 \\
\hline & Observations & 28 & 27 & 24 & 26 & 28 & 28 \\
\hline \multirow{3}{*}{$\begin{array}{l}\text { Other } \\
\text { developing }\end{array}$} & $\%$ Countercyclical & 1.9 & 0.0 & 0.0 & 0.0 & 11.1 & 33.3 \\
\hline & \% Procyclical & 14.8 & 36.7 & 7.1 & 43.3 & 5.6 & 9.3 \\
\hline & Observations & 54 & 30 & 14 & 30 & 54 & 54 \\
\hline \multirow{3}{*}{$\begin{array}{l}\text { High } \\
\text { remittance }\end{array}$} & $\%$ Countercyclical & 3.3 & 2.1 & 3.2 & 2.2 & 13.8 & 45.0 \\
\hline & $\%$ Procyclical & 20.0 & 42.6 & 3.2 & 45.7 & 5.2 & 3.3 \\
\hline & Observations & 60 & 47 & 31 & 46 & 58 & 60 \\
\hline \multirow{3}{*}{$\begin{array}{l}\text { RCI } \\
\text { countries }\end{array}$} & $\%$ Countercyclical & 2.9 & 3.2 & 4.8 & 0.0 & 15.2 & 48.6 \\
\hline & $\%$ Procyclical & 31.4 & 41.9 & 4.8 & 50.0 & 0.0 & 2.9 \\
\hline & Observations & 35 & 31 & 21 & 30 & 33 & 35 \\
\hline
\end{tabular}

Source: Authors' estimates.

Note: Cyclicality is defined as the correlation between the detrended real series of GDP and the relevant inflow. A series is considered procyclical if the correlation between the cyclical components of the flow and output is positive and statistically different from zero, countercyclical if it is negative and statistically different from zero, and acyclical if the correlation is not statistically different from zero. Total number of countries, percent procyclical, and percent countercyclical are provided for each country grouping. FDI measures foreign direct investment. ODA covers official development assistance and aid, and Total inflows is the sum of FDI, portfolio investment (including equity and debt), financial derivatives, and other investments. Each time series is decomposed into trend and cyclical components using a Hodrick-Prescott (HP) filter and the sample period is 1980-2012. See the note to figure 2 for definitions of the country groupings. 


\section{Table 5 Cyclicality of Remittances by Different Methodologies}

(Correlation coefficient - Panel A; \% of countries - Panels B and C)

\begin{tabular}{|c|c|c|c|c|c|}
\hline & \multicolumn{5}{|c|}{ A: Median Correlation of Remittances with GDP } \\
\hline & $\begin{array}{c}\text { All } \\
\text { Real } \\
\end{array}$ & $\begin{array}{c}\text { Broner et al. } \\
2013 \\
\end{array}$ & $\begin{array}{c}\text { Kaminsky, Reinhart, and } \\
\text { Végh. } 2005\end{array}$ & $\begin{array}{c}\text { Chami et al. } \\
2008 \\
\end{array}$ & $\begin{array}{c}\text { Pallage and } \\
\text { Robe } 2001 \\
\end{array}$ \\
\hline \multirow{5}{*}{$\begin{array}{l}\text { All Countries } \\
\text { Emerging } \\
\text { markets } \\
\text { Other } \\
\text { economies } \\
\text { High } \\
\text { remittance } \\
\text { RCI } \\
\text { countries }\end{array}$} & 0.08 & 0.07 & 0.22 & -0.04 & -0.23 \\
\hline & 0.00 & 0.08 & 0.20 & -0.09 & -0.31 \\
\hline & 0.11 & 0.05 & 0.23 & -0.03 & -0.13 \\
\hline & 0.19 & 0.06 & 0.37 & -0.02 & -0.18 \\
\hline & 0.27 & 0.16 & 0.53 & 0.03 & -0.16 \\
\hline & \multicolumn{5}{|c|}{ B: Correlation of Remittances with GDP (\% Countercyclical) } \\
\hline All countries & 7.3 & 4.6 & 6.4 & 17.4 & 37.6 \\
\hline $\begin{array}{l}\text { Emerging } \\
\text { markets }\end{array}$ & 17.9 & 3.6 & 17.9 & 28.6 & 50.0 \\
\hline $\begin{array}{l}\text { Other } \\
\text { economies }\end{array}$ & 1.9 & 7.4 & 1.9 & 13.0 & 24.1 \\
\hline $\begin{array}{l}\text { High } \\
\text { remittance }\end{array}$ & 3.3 & 5.0 & 3.3 & 15.0 & 35.0 \\
\hline \multirow[t]{2}{*}{$\begin{array}{l}\mathrm{RCI} \\
\text { countries } \\
\end{array}$} & 2.9 & 5.7 & 2.9 & 5.7 & 28.6 \\
\hline & \multicolumn{5}{|c|}{ C: Correlation of Remittances with GDP (\% Procyclical) } \\
\hline All countries & 14.7 & 13.8 & 38.5 & 2.8 & 2.8 \\
\hline $\begin{array}{l}\text { Emerging } \\
\text { markets }\end{array}$ & 7.1 & 14.3 & 39.3 & 3.6 & 7.1 \\
\hline $\begin{array}{l}\text { Other } \\
\text { economies }\end{array}$ & 14.8 & 18.5 & 37.0 & 3.7 & 1.9 \\
\hline $\begin{array}{l}\text { High } \\
\text { remittance }\end{array}$ & 20.0 & 18.3 & 53.3 & 3.3 & 3.3 \\
\hline $\begin{array}{l}\text { RCI } \\
\text { countries }\end{array}$ & 31.4 & 20.0 & 68.6 & 5.7 & 2.9 \\
\hline
\end{tabular}

Source: Authors' estimates.

Note: Remittances are considered procyclical if the correlation between the cyclical components of remittances and output is positive and statistically different from zero, countercyclical if it is negative and statistically different from zero, and acyclical if the correlation is not statistically different from zero. Median correlation, percent countercyclical, and percent procyclical are provided for each country grouping in Panels A, B, and C, respectively. Each time series is decomposed into trend and cyclical components using a Hodrick-Prescott (HP) filter and the sample period is 1980-2012. Remittances and GDP are in U.S. dollars and deflated by home GDP deflator in column (1). Column (2) uses the normalization method by Broner et al. (2013). Remittances are first normalized by trend GDP and then standardized by de-meaning at the country level and division by its standard deviation. Then remittances and real GDP growth are detrended using an HP filter with parameter 10,000 to remove possible linear trends before computing the correlations. Column (3) reports the correlation between the cyclical components of real GDP and nominal remittances (Kaminsky, Reinhart, and Végh 2005). Columns (4) and (5) use the methodologies by Chami et al. (2008) and Pallage and Robe (2001), respectively. The correlations are between the cyclical components of real GDP and the ratio of remittances to GDP in the former and between GDP and remittances both divided by an import price deflator in the latter. See the note to figure 2 for definitions of the country groupings. 


\section{Table 6 Remittances and Capital Inflows during Sudden Stops}

(Index numbers)

\begin{tabular}{|c|c|c|c|c|c|c|c|c|c|c|}
\hline \multirow[t]{2}{*}{ Timeline } & \multicolumn{2}{|c|}{ All Countries } & \multicolumn{2}{|c|}{$\begin{array}{c}\text { Emerging } \\
\text { Markets }\end{array}$} & \multicolumn{2}{|c|}{ Other Developing } & \multicolumn{2}{|c|}{$R C I$} & \multicolumn{2}{|c|}{ High Remittance } \\
\hline & Remit & Inflows & Remit & Inflows & Remit & Inflows & Remit & Inflows & Remit & Inflows \\
\hline-2 & 100.0 & 100.0 & 100.0 & 100.0 & 100.0 & 100.0 & 100.0 & 100.0 & 100.0 & 100.0 \\
\hline-1 & 111.7 & 135.4 & 118.0 & 219.3 & 117.2 & 201.6 & 119.6 & 175.2 & 116.0 & 168.1 \\
\hline 0 & 120.9 & 90.3 & 131.7 & 56.6 & 125.8 & 128.0 & 133.7 & 106.9 & 125.4 & 108.8 \\
\hline 1 & 126.2 & 84.3 & 136.5 & 165.3 & 117.0 & 66.2 & 127.2 & 70.2 & 123.1 & 71.5 \\
\hline 2 & 142.7 & 126.6 & 160.0 & 207.1 & 129.9 & 99.1 & 135.9 & 108.9 & 136.4 & 108.6 \\
\hline
\end{tabular}

Source: Authors' calculations.

Note: The timeline is indicated in the first column: -2 indicates value two years before the sudden stop, -1 a year before, 0 is the year of the sudden stop, 1 is a year after the sudden stop, and 2 is two years after the sudden stop. Values are averages of remittances and net capital inflows for emerging markets and developing economies that have experienced sudden stop episodes. Index numbers are calculated with a base of 100 for the period two years before the sudden stop year $(-2)$. Capital inflows are net, that is, the difference between amounts brought in by foreign entities and the amounts sent out by domestic entities. Data are for episodes after 1990. See the note to figure 2 for definitions of the country groupings. 
Table 7 Growth Rates of Remittances and Capital Inflows during Sudden Stops (Growth rates in \%)

\begin{tabular}{c|cc|cc|cc|cc|cc}
\hline Timeline & \multicolumn{2}{|c|}{ All Countries } & \multicolumn{2}{c|}{$\begin{array}{c}\text { Emerging } \\
\text { Markets }\end{array}$} & \multicolumn{2}{c|}{ Other Developing } & & \multicolumn{2}{c|}{ RCI } & \multicolumn{2}{c}{ High Remittance } \\
& Remit & Inflows & Remit & Inflows & Remit & Inflows & Remit & Inflows & Remit & Inflows \\
\hline$-\mathbf{2}$ & 11.4 & 7.8 & 11.7 & -3.2 & 13.2 & 14.4 & 12.5 & 10.0 & 15.6 & 11.8 \\
$-\mathbf{1}$ & 11.7 & 11.9 & 17.0 & 26.0 & 12.6 & 16.2 & 11.2 & 20.7 & 14.4 & 17.6 \\
$\boldsymbol{0}$ & 6.6 & -14.8 & 6.8 & -25.2 & 10.6 & -25.1 & 8.7 & -25.9 & 8.5 & -21.5 \\
$\mathbf{1}$ & 5.7 & -10.0 & 7.5 & -10.7 & 7.2 & -16.3 & 2.2 & -6.7 & 4.6 & -12.4 \\
$\mathbf{2}$ & 7.6 & -8.5 & 10.6 & -2.0 & -0.1 & -2.5 & 5.4 & 6.0 & 9.1 & -2.0 \\
\hline
\end{tabular}

Source: Authors' calculations.

Notes: The timeline is indicated in the first column: -2 indicates value two years before the sudden stop, -1 a year before, 0 is the year of the sudden stop, 1 is a year after the sudden stop and 2 is two years after the sudden stop. Values are averages of growth rates of nominal remittances and net capital inflows across relevant country groups. Capital inflows are net, that is the difference between amounts brought in by foreign entities and the amounts sent out by domestic entities. Data are for episodes after 1990 . See the note to figure 2 for definitions of the country groupings. 


\section{Table 8 Remittances and Capital Inflows during Currency Crises}

(Index numbers)

\begin{tabular}{|c|c|c|c|c|c|c|c|c|c|c|}
\hline \multirow[t]{2}{*}{ Timeline } & \multicolumn{2}{|c|}{ All Countries } & \multicolumn{2}{|c|}{$\begin{array}{c}\text { Emerging } \\
\text { Markets }\end{array}$} & \multicolumn{2}{|c|}{ Other Developing } & \multicolumn{2}{|c|}{$R C I$} & \multicolumn{2}{|c|}{ High Remittance } \\
\hline & Remit & Inflows & Remit & Inflows & Remit & Inflows & Remit & Inflows & Remit & Inflows \\
\hline-2 & 100.0 & 100.0 & 100.0 & 100.0 & 100.0 & 100.0 & 100.0 & 100.0 & 100.0 & 100.0 \\
\hline-1 & 103.2 & 95.5 & 110.5 & 112.3 & 104.2 & 96.7 & 116.4 & 182.0 & 117.4 & 132.9 \\
\hline 0 & 115.8 & 43.1 & 163.3 & 41.3 & 101.6 & 85.8 & 120.6 & 57.9 & 125.1 & 67.2 \\
\hline 1 & 105.7 & 32.4 & 140.4 & 32.3 & 100.9 & 52.9 & 104.5 & 17.5 & 116.3 & 42.1 \\
\hline 2 & 114.6 & 34.4 & 159.0 & 44.6 & 109.9 & 15.0 & 89.1 & 14.6 & 109.4 & 27.3 \\
\hline
\end{tabular}

Source: Authors' calculations.

Note: Crises are based on Laeven and Valencia (2013). The timeline is indicated in the first column: -2 indicates value two years before the crisis, -1 a year before, 0 is the year of the crisis, 1 is a year after the crisis and 2 is two years after the crisis. Values are averages of remittances and net capital inflows for emerging markets and developing economies that have experienced sudden stop episodes. Index numbers are calculated with a base of 100 for the period two years before the sudden stop year $(-2)$. Capital inflows are net, that is the difference between amounts brought in by foreign entities and the amounts sent out by domestic entities. Data are for episodes after 1990. See the note to figure 2 for definitions of the country groupings. 
Table 9 Remittances and Capital Inflows during Banking Crises

(Index numbers)

\begin{tabular}{c|cc|cc|cc|cc|cc}
\hline Timeline & \multicolumn{2}{|c|}{ All Countries } & \multicolumn{2}{c|}{$\begin{array}{c}\text { Emerging } \\
\text { Markets }\end{array}$} & \multicolumn{2}{c|}{ Other Developing } & & \multicolumn{2}{c|}{ RCI } & \multicolumn{2}{c}{ High Remittance } \\
& Remit & Inflows & Remit & Inflows & Remit & Inflows & Remit & Inflows & Remit & Inflows \\
\hline$-\mathbf{2}$ & 100.0 & 100.0 & 100.0 & 100.0 & 100.0 & 100.0 & 100.0 & 100.0 & 100.0 & 100.0 \\
$-\mathbf{1}$ & 116.0 & 128.0 & 118.8 & 236.0 & 141.7 & 190.1 & 115.4 & 104.9 & 114.7 & 105.6 \\
$\boldsymbol{0}$ & 120.1 & 72.5 & 114.6 & -97.2 & 169.7 & 144.0 & 119.2 & 113.6 & 118.7 & 86.9 \\
$\mathbf{1}$ & 116.1 & 97.7 & 120.8 & 5.1 & 157.2 & -1.6 & 106.4 & 41.1 & 112.3 & 35.0 \\
$\mathbf{2}$ & 123.9 & 16.7 & 132.1 & -4.2 & 173.1 & 90.4 & 106.2 & 52.2 & 115.0 & 33.1 \\
\hline
\end{tabular}

Source: Authors' calculations.

Note: Crises are based on Laeven and Valencia (2013). The timeline is indicated in the first column: -2 indicates value two years before the crisis, -1 a year before, 0 is the year of the crisis, 1 is a year after the crisis and 2 is two years after the crisis. Values are averages of remittances and net capital inflows for emerging markets and developing economies that have experienced sudden stop episodes. Index numbers are calculated with a base of 100 for the period two years before the sudden stop year $(-2)$. Capital inflows are net, that is the difference between amounts brought in by foreign entities and the amounts sent out by domestic entities. Data are for episodes after 1990. See the note to figure 2 for definitions of the country groupings. 
Table 10 Remittances and Capital Inflows During Banking, Currency or Sovereign Debt Crises

(Index numbers)

\begin{tabular}{|c|c|c|c|c|c|c|c|c|c|c|}
\hline \multirow[t]{2}{*}{ Timeline } & \multicolumn{2}{|c|}{ All Countries } & \multicolumn{2}{|c|}{$\begin{array}{c}\text { Emerging } \\
\text { Markets }\end{array}$} & \multicolumn{2}{|c|}{ Other Developing } & \multicolumn{2}{|c|}{$R C I$} & \multicolumn{2}{|c|}{ High Remittance } \\
\hline & Remit & Inflows & Remit & Inflows & Remit & Inflows & Remit & Inflows & Remit & Inflows \\
\hline-2 & 100.0 & 100.0 & 100.0 & 100.0 & 100.0 & 100.0 & 100.0 & 100.0 & 100.0 & 100.0 \\
\hline-1 & 110.9 & 115.9 & 104.4 & 158.5 & 119.4 & 210.3 & 100.9 & 100.5 & 110.3 & 101.9 \\
\hline 0 & 100.1 & 62.5 & 95.5 & -40.4 & 111.8 & 160.4 & 95.7 & 106.2 & 102.0 & 83.4 \\
\hline 1 & 108.2 & 85.5 & 106.4 & 10.1 & 115.6 & 18.6 & 95.7 & 34.8 & 109.2 & 30.6 \\
\hline 2 & 118.3 & 19.5 & 122.0 & 17.5 & 123.0 & 109.3 & 98.1 & 55.8 & 114.6 & 37.7 \\
\hline
\end{tabular}

Source: Authors' calculations.

Note: Crises are based on Laeven and Valencia (2013). The timeline is indicated in the first column: -2 indicates value two years before the crisis, -1 a year before, 0 is the year of the crisis, 1 is a year after the crisis and 2 is two years after the crisis. Values are averages of remittances and net capital inflows for emerging markets and developing economies that have experienced sudden stop episodes. Index numbers are calculated with a base of 100 for the period two years before the sudden stop year (--2). Capital inflows are net, that is the difference between amounts brought in by foreign entities and the amounts sent out by domestic entities. Data are for episodes after 1990. See the note to figure 2 for definitions of the country groupings. 
Table 11 Consumption Stability Regressions

\begin{tabular}{|c|c|c|c|c|c|c|c|c|}
\hline & Baseline & Baseline & De jure & Equity & FDI & De jure & Equity & FDI \\
\hline \multirow[t]{2}{*}{ Output growth } & $0.756^{* * *}$ & $0.814 * * *$ & $0.752 * * *$ & $0.834 * * *$ & $0.815^{* * *}$ & $0.845^{* * *}$ & $0.878 * * *$ & $0.841 * * *$ \\
\hline & {$[0.072]$} & {$[0.048]$} & {$[0.059]$} & {$[0.058]$} & {$[0.053]$} & {$[0.068]$} & {$[0.078]$} & {$[0.067]$} \\
\hline \multirow[t]{2}{*}{ Remit } & & 0.079 & & 0.056 & 0.030 & 0.051 & 0.048 & 0.030 \\
\hline & & {$[0.062]$} & & {$[0.076]$} & [0.049] & {$[0.056]$} & {$[0.081]$} & {$[0.051]$} \\
\hline \multirow{2}{*}{$\begin{array}{c}\text { Remit } \times \text { Output } \\
\text { growth }\end{array}$} & & $-1.956 * *$ & & $-2.136 * * *$ & $-1.193 * *$ & $-1.217 *$ & $-2.164 * * *$ & $-1.163 *$ \\
\hline & & {$[0.973]$} & & {$[0.787]$} & [0.599] & {$[0.657]$} & {$[0.802]$} & {$[0.613]$} \\
\hline \multirow{2}{*}{$\begin{array}{l}\text { De facto } \times \text { Output } \\
\text { growth }\end{array}$} & & & & -0.308 & -0.112 & & -0.255 & -0.011 \\
\hline & & & & {$[0.317]$} & {$[0.455]$} & & {$[0.315]$} & {$[0.453]$} \\
\hline \multirow[t]{2}{*}{ De jure $\times$ Output growth } & & & -0.024 & & & -0.098 & -0.092 & -0.104 \\
\hline & & & {$[0.086]$} & & & {$[0.088]$} & [0.089] & {$[0.085]$} \\
\hline \multirow[t]{2}{*}{ Constant } & $0.022 * * *$ & $0.015^{*}$ & $0.021 * * *$ & 0.000 & 0.007 & 0.013 & 0.017 & 0.008 \\
\hline & {$[0.008]$} & [0.008] & {$[0.007]$} & {$[0.007]$} & {$[0.008]$} & {$[0.008]$} & [0.011] & {$[0.008]$} \\
\hline Observations & 3,226 & 2,831 & 3,030 & 2,026 & 2,731 & 2,762 & 1,999 & 2,671 \\
\hline$R^{2}$ & 0.252 & 0.266 & 0.224 & 0.259 & 0.259 & 0.256 & 0.254 & 0.239 \\
\hline Number of countries & 109 & 109 & 109 & 105 & 109 & 109 & 105 & 109 \\
\hline
\end{tabular}

Source: Authors' estimates.

Note: The dependent variable is the country-specific consumption growth, Output Growth measures country-specific GDP growth, Remit measures the ratio of remittance inflows to GDP, and De jure is the normalized index of financial openness derived from Chinn-Ito (2006). Measures of FDI (foreign direct investment) and equity (portfolio equity) are derived from the updated and extended version of the data set constructed by Lane and Milesi-Ferretti (2007). A negative $\beta_{2}$ suggests that remittances help lower the correlation between country-specific consumption and output growth. Significance at the 5 percent and 1 percent levels are indicated by ** and ***, respectively. 
Appendix: Data and List of Sudden Stops

Table A.1 Data Sources

\begin{tabular}{|c|c|c|}
\hline Variable & Source & Frequency \\
\hline GDP (constant 2005 US\$) & WDI & Annual \\
\hline GDP per capita (constant 2005 US\$) & WDI & Annual \\
\hline GDP (current US\$) & WDI & Annual \\
\hline GDP deflator & WDI & Annual \\
\hline $\begin{array}{l}\text { Official development assistance and aid (current } \\
\text { US\$) }\end{array}$ & WDI & Annual \\
\hline Private household consumption (constant 2005 US\$) & WDI & Annual \\
\hline Total exports (current US\$) & WDI & Annual \\
\hline Net exports (current US\$) & WDI & Annual \\
\hline Remittances* (current US\$) & WDI & Annual \\
\hline Total capital inflows** (current US\$) & Global Capital Flows & Annual, Quarterly \\
\hline Portfolio equity** (current US\$) & $\begin{array}{l}\text { Global Capital Flows; Lane and Milesi- } \\
\text { Ferretti (2007) }\end{array}$ & Annual, Quarterly \\
\hline Foreign direct investment (FDI)** (current US\$) & Lane and Milesi-Ferretti (2007) & Annual \\
\hline Financial openness $* * *$ & Chinn-Ito (2006) & Annual \\
\hline $\begin{array}{l}\text { International migrant stock by country of origin and } \\
\text { destination }\end{array}$ & $\begin{array}{l}\text { United Nations Population Division } \\
\text { (2013) }\end{array}$ & Annual \\
\hline Exchange rate regime (IMF classification) & Ilzetzki, Reinhart and Rogoff (2008) & Annual \\
\hline
\end{tabular}

Note: WDI is the World Bank's World Development Indicators data set and Global Capital Flows is a data set provided by the World Bank's Development Prospects Group. Variables in current U.S. dollars are divided by a home-GDP deflator to obtain them in real terms wherever needed.

* Remittances include the sum of personal transfers and compensation of employees.

** FDI measures foreign direct investment and total inflows is the sum of FDI, portfolio investment (including equity and debt), financial derivatives, and other investments. These measures are in net (new investment inflows less disinvestment) in the reporting economy from foreign investors. Data from Lane and Milesi-Ferretti (2007) are used only in the consumption-smoothing regressions for robustness check.

*** Financial openness is a normalized de jure index (updated to 2012) that keeps track of the restrictions on cross-border financial transactions reported in the IMF's Annual Report on Exchange Arrangements and Exchange Restrictions. 


\section{Table A.2 List of Sudden Stop Events}

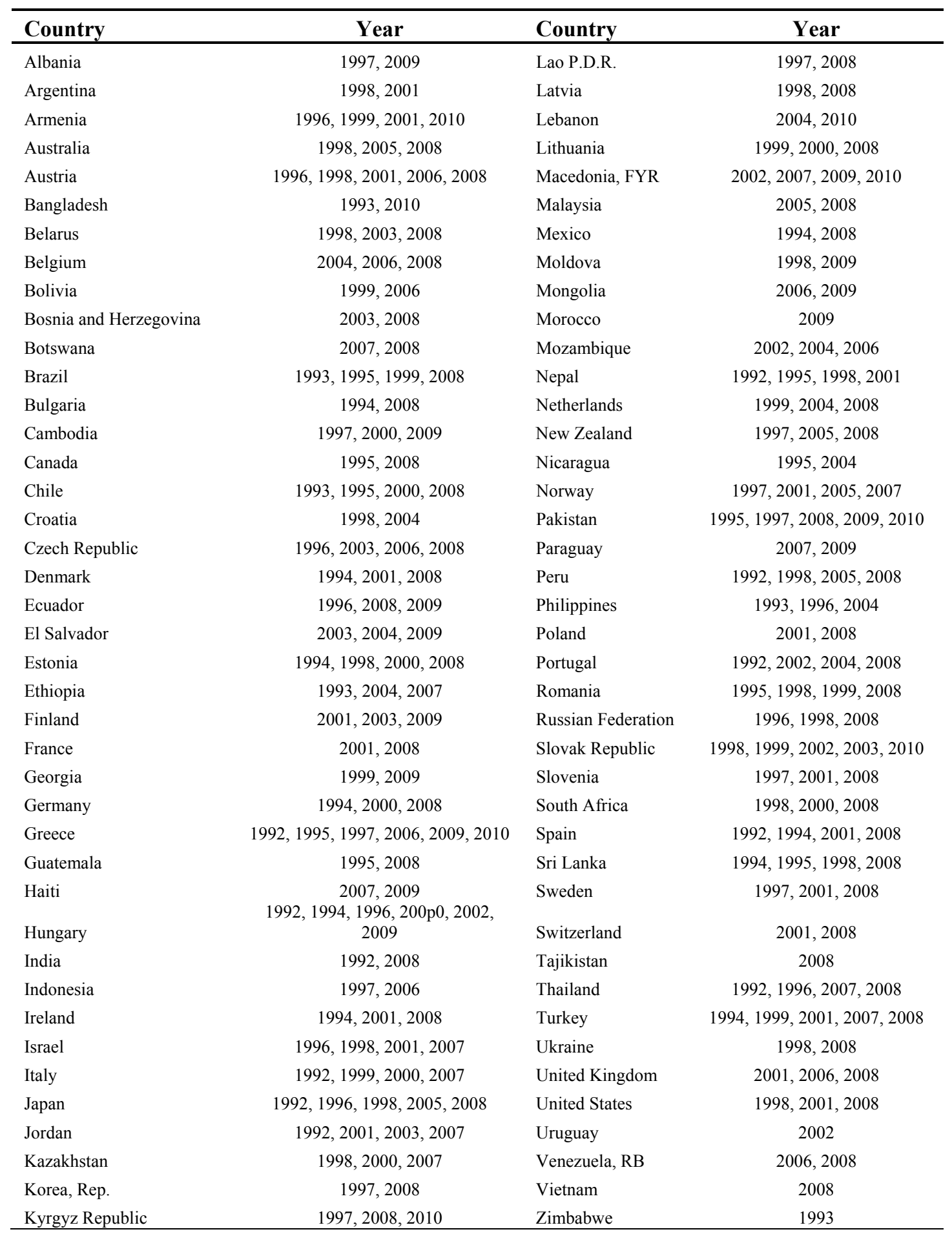

Note: Sudden stops are defined following Forbes and Warnock (2012). See section 4 for details. 